\title{
Pesticides, insecticides and male infertility
}

\section{Priyanka Roy, Pranay Kumar Phukan*, Debojit Changmai, Surajeet Boruah}

Department of Obstetrics and Gynaecology, Assam Medical College and Hospital, Dibrugarh, Assam, India

Received: 26 February 2017

Accepted: 17 June 2017

\section{*Correspondence:}

Dr. Pranay Kumar Phukan,

E-mail: pranayp4@yahoo.com

Copyright: (C) the author(s), publisher and licensee Medip Academy. This is an open-access article distributed under the terms of the Creative Commons Attribution Non-Commercial License, which permits unrestricted non-commercial use, distribution, and reproduction in any medium, provided the original work is properly cited.

\section{ABSTRACT}

Background: Pesticides, insecticides can damage the male reproductive system in a number of ways. They may cause reproductive toxicity with direct damage to the structure of the cells or as a result of biotransformation into metabolites. They can alter DNA structure. They may also act like hormones in the endocrine system and disrupt the function of the natural endogenous hormones, when doing so they are often called endocrine disrupting chemicals. The objective of the study was to evaluate the association of infertility with pesticide and insecticide exposure among the infertile male patients attending Out Patient Department of Assam Medical College and Hospital.

Methods: The pesticides and insecticides used by the population were cypermethrin, thiaclopride, acetamiprid, emmacetin benzoate A total of 55 oligospermic infertile male patients were taken for the study. Twenty-seven among them were exposed to pesticides and rest twenty-eight unexposed cases were taken as control group. Semen analysis was done along with serum FSH, LH and Testosterone. Scrotal ultrasonography of the subjects was also done. One way ANOVA test and t-test assuming two unequal variances were applied to find out the statistical significance of the association of pesticides with their infertility. $\mathrm{p}<0.05$ was taken to be significant.

Results: A significant decrease in sperm concentration was found in the exposed group. Also, a significant increase in serum LH was found in the exposed group. A significant decrease in sperm concentration and serum testosterone along with a significant increase in serum FSH and LH was found with increase in duration of exposure to pesticides and insecticides.

Conclusions: The gonadotoxic effect of pesticides and insecticides was reflected from the study and it was concluded that pesticide and insecticide exposure has got a definite relation with the infertility of the subjects evaluated in the study.

Keywords: Insecticides, Male infertility, Pesticides

\section{INTRODUCTION}

The World Health Organization (WHO) defined infertility as the inability of a sexually active couple to achieve pregnancy despite unprotected intercourse for a period of greater than 12 months. The European Society for Human Reproduction and Embryology (ESHRE) defines infertility as failure of pregnancy to occur within 2 years of regular coital exposure. ${ }^{1}$ WHO defines Pesticides as chemical compounds that are used to kill pests, including insects, rodents, fungi and unwanted plants (weeds). ${ }^{2}$

Pesticides can damage the male reproductive system in a number of ways.

- Reproductive toxicity with direct damage to the structure of the cells

- Altering DNA structure, causing gene mutations that may result in birth defects or an inability to conceive. 
- Change the way genes are expressed called epigenetic effect.

- They may act as endocrine disrupting chemicals (EDC). ${ }^{3}$

- Pyrethroids insecticides metabolites are associated with reduced sperm concentration, motility and morphology, and increased DNA damage. ${ }^{4}$

- The neonicotinides have shown to reduce sperm viability and reduce living sperm quality in male honey bees. ${ }^{5}$

- Emmacetin benzoate, a biopesticide derivative of avermectins, is shown to cause an absolute decrease in testicular weight and testicular damage of male rats exposed to it. ${ }^{6}$

The objective of the study was to evaluate the association of infertility with pesticide and insecticide exposure among the infertile male patients attending Out Patient Department of Assam Medical College and Hospital.

\section{METHODS}

Pesticides/Insecticides studied: The pesticides and insecticides used by the population were cypermethrin, thiaclopride, acetamiprid, emmacetin benzoate. These were sprayed twice in a year. Sample size: A total of 55 oligospermic infertile male patients were taken for the study out of which 27 cases were exposed to pesticides and insecticides, 19 of them were tea garden workers and 8 were farmers. Rest 28 unexposed cases were taken as control group. Investigations done: Semen analysis was done along with serum FSH, LH, Testosterone and Prolactin. Scrotal ultrasonography of the subjects was also done. Statistics applied: One way ANOVA test and $t$ test of two unequal variance was applied to find out the statistical significance of the association of pesticides with their infertility. $\mathrm{p}<0.05$ was taken to be significant.

\section{RESULTS}

It was observed that there was a significant decrease $(\mathrm{p}=$ 0.04 ) in sperm concentration and a significant increase $(\mathrm{p}=0.008)$ in serum LH among the exposed group to pesticides and insecticides in comparison with the nonexposed group. It was further seen that there was a significant increase in serum FSH, LH (p 0.046 and 0.045 respectively) with increase in the duration of exposure to pesticides and insecticide with a significant decrease in sperm density and serum testosterone (p 0.032 and 0.0003 respectively) with the same. No significant change in serum Prolactin was observed. There was also a significant decrease in testicular size with increase in duration of exposure to pesticides and insecticides.

Table 1: Comparison between the exposed and unexposed groups in relation with sperm density and hormones.

\begin{tabular}{|llll|}
\hline Pesticides/insecticides (in years) & Exposed cases & Unexposed cases & p value \\
\hline Number $(\mathrm{n}=55)$ & 27 & 28 & Mean \pm SD \\
\hline Sperm Concentration $($ million/ml) & Mean \pm SD & $6.15 \pm 3.20$ & 0.04 \\
\hline Serum FSH $(\mathrm{mIU} / \mathrm{ml})$ & $4.96 \pm 3.8$ & $16.94 \pm 14.54$ & 0.40 \\
\hline Serum LH $(\mathrm{mIU} / \mathrm{ml})$ & $17.98 \pm 10.39$ & $7.74 \pm 4.58$ & 0.008 \\
\hline Serum Testosterone $(\mathrm{ng} / \mathrm{ml})$ & $12.49 \pm 8.49$ & $4.62 \pm 3.45$ & 0.15 \\
\hline Serum Prolactin $(\mathrm{ng} / \mathrm{ml})$ & $5.29 \pm 3.45$ & $12.31 \pm 2.57$ & 0.08 \\
\hline
\end{tabular}

Table 2: Relation of sperm density and hormone parameters with duration of pesticide, insecticide exposure.

\begin{tabular}{|c|c|c|c|c|c|c|c|c|c|}
\hline Pesticides (in years) & $1-2$ & & $3-5$ & & $6-8$ & & $9-10$ & & $p$ value \\
\hline & $\mathrm{n}$ & $\%$ & $\mathrm{n}$ & $\%$ & $\mathrm{n}$ & $\%$ & $\mathrm{n}$ & $\%$ & \\
\hline Number $(n=5)$ & 3 & 5.45 & 9 & 16.3 & 11 & 20 & 4 & 7.27 & \\
\hline & Mean & \pm S.D & Mean & \pm S.D & Mean & \pm S.D & Mean & \pm S.D & \\
\hline Sperm concentration (million/ml) & 7.03 & 2.57 & 6.89 & 2.08 & 6.22 & 3.59 & 3.66 & 4.39 & 0.0325 \\
\hline Serum FSH (mIU/ml) & 7.93 & 2.17 & 13.93 & 5.78 & 21.19 & 9.54 & 25.82 & 16.45 & 0.0463 \\
\hline Serum LH (mIU/ml) & 5.73 & 0.50 & 8.83 & 5.23 & 15.15 & 8.71 & 18.45 & 11.85 & 0.0456 \\
\hline Serum testosterone $(\mathrm{ng} / \mathrm{ml})$ & 10.67 & 1.17 & 6.96 & 2.73 & 3.50 & 2.59 & 2.45 & 0.56 & 0.0003 \\
\hline Serum prolactin $(\mathrm{ng} / \mathrm{ml})$ & 12.97 & 0.86 & 10.42 & 3.12 & 11.56 & 2.67 & 11.35 & 1.77 & 0.5233 \\
\hline
\end{tabular}

\section{Pesticide/insecticide exposure and testicular size on scrotal USG}

Sixteen cases $(59 \%)$ out of twenty-seven oligospermic individuals who were exposed to pesticides and insecticides showed a decreased testicular volume on scrotal ultrasonography.

Their distribution according to the duration of pesticide and insecticide exposure are as follows. 
Table 3: Decreased testicular size on scrotal USG.

\begin{tabular}{|lll|}
\hline $\begin{array}{l}\text { Duration of } \\
\text { exposure to } \\
\text { pesticide (years) }\end{array}$ & Total cases & $\begin{array}{l}\text { Total no. of } \\
\text { cases with } \\
\text { decreased testis }\end{array}$ \\
\hline $1-2$ & 3 & $2(67 \%)$ \\
\hline $3-5$ & 9 & $4(44 \%)$ \\
\hline $6-8$ & 11 & $7(64 \%)$ \\
\hline $9-10$ & 4 & $3(75 \%)$ \\
\hline
\end{tabular}

Fifteen cases out of the 28 non-exposed group showed decreased testicular size on scrotal USG.

\section{Other associated factors}

Age: The no of cases with age more than 35 years were almost same in both the groups.

Table 4: Age.

\begin{tabular}{|ll|}
\hline Groups & Age $\geq 35$ years (no of cases) \\
\hline Exposed & 13 \\
\hline Unexposed & 18 \\
\hline
\end{tabular}

Table 5: Smoking.

\begin{tabular}{|ll|}
\hline Groups & No of cases who smoked \\
\hline Exposed & 12 \\
\hline Unexposed & 6 \\
\hline
\end{tabular}

The no of occasional alcohol drinkers was more in the exposed group. They usually consumed country liquor, about two glasses twice in a week. None were heavy drinkers.

Table 6: Alcohol.

\begin{tabular}{|l|l|}
\hline Groups & $\begin{array}{l}\text { No. of cases on alcohol } \\
\text { (occasional drinkers) }\end{array}$ \\
\hline Exposed & 26 \\
\hline Unexposed & 5 \\
\hline
\end{tabular}

\section{Associated diseases}

The contribution of diseases like mumps, varicocele, hydrocele, diabetes, tuberculosis in harming the reproductive potential was more in the unexposed group.

Table 7: Associated diseases.

\begin{tabular}{|lllllll|} 
Groups & Mumps & Varicocele & Hydrocele & Tuberculosis & Diabetes & Hypothyroidism \\
\hline Exposed & 3 & 1 & 0 & 0 & 0 & 0 \\
\hline Unexposed & 4 & 6 & 3 & 1 & 5 & 2 \\
\hline
\end{tabular}

\section{DISCUSSION}

Pyrethroids are a group of synthetic (man-made) chemicals used as pesticides in a variety of locations including commercial, agricultural, homes communities, restaurants, hospitals, schools, and as a topical head lice. Pyrethroids are chemicals that are very similar in structure to the pyrethrins (natural insecticides derived from the chrysanthemum plant), but are often more toxic to insects, as well as mammals, and last longer in the environment than pyrethrins. Many pyrethroids have also been linked to disruption of the endocrine system. ${ }^{(7)}$ The relationship between environmental exposure to pyrethroids and DNA damage in human sperm has been previously investigated in few studies. In a study done by Joanna J et al 286 men under 46 years of age with a normal sperm concentration were recruited from an infertility clinic in Poland. The pyrethroids metabolites were analysed in the urine. A positive association was observed between pyrethroid metabolite (3phenoxybenzoic acid (3PBA), cis-3-(2,2-dichlorovinyl)2,2-dimethylcyclopropane carboxylic acid (CDCCA), trans-3-(2,2-dichlorovinyl)-2,2-dimethylcyclopropane carboxylic acid (TDCCA), and cis-2,2-dibromovinyl-2,2dimethylcyclopropane-carboxylic acid (DBCA) CDCCA) $>50^{\text {th }}$ percentile and the percentage of medium DNA fragmentation index (MDFI) and percentage of immature sperms $(p=0.04, p=0.04$ respectively $) .{ }^{8}$ In a study by Meeker JD et al they found evidence that urinary pyrethroid insecticide metabolites (3PBA, cis-DCCA and trans-DCCA) are positively associated with FSH and LH, and inversely associated with inhibin $\mathrm{B}$, testosterone, and free androgen index. ${ }^{4}$ Pesticides like pyrethroids, also reduces testosterone concentrations in male after acute exposure during exposure season. ${ }^{9}$ Cypermethrin, one of the major pesticides used by the subjects in the present study comes under the pyrethoid group of pesticides. Cypermethrin is one of the most widely used synthetic pesticides for agricultural and domestic purposes, globally. It extends the opening of sodium channels in the central nervous system leading to hypo-polarization and hyper-excitation of the neurons. Additionally, it induces neurotoxicity by modulating the level of gammaaminobutyric acid (GABA). Furthermore, cypermethrinmediated neurotoxicity is contributed by its ability to induce free radical generation. The oxidative stress is implicated in the cypermethrin-mediated neurotoxicity. The major contributors of oxidative stress are excessive production of reactive oxygen species (ROS) and reactive nitrogen species in the cells or tissues exposed to cypermethrin or reduced level of components of the antioxidant machinery. Cytochrome P450 2E1 (CYP2E1) 
is recognized as one of the major contributors involved in cypermethrin metabolism leading to generation of ROS and oxidative stress via mixed function oxidase Cypermethrin also causes DNA damage and reduces mitotic and nuclear divisions. ${ }^{10}$ A study done by Zalata et al demonstrated a significant decrease in sperm motion, sperm function and increased sperm DNA damage in the cypermethrin treated semen samples which were exposed to cypermethrin. ${ }^{11}$ Cypermethrin was also found to cause testicular damage causing impairment of seminiferous tubules structure and decreased testosterone production in male rats with decreased spermatogenesis and raised serum $\mathrm{FSH}$ in these rats. ${ }^{12}$

Acetamiprid (ACE), another insecticide used by the study population, is one of the major member in the family of neonicotinoid insecticides, which are synthesized with a higher selectivity to insects. It exhibits a systemic translaminar action. It exhibits tripe action-ovicidal, adulticide and larvicidal. $\mathrm{Gu}$ YH et al studied the in vitro effects of ACE on mammalian reproduction by using an integrated testing strategy for reproductive toxicology, which covered sperm quality and sperm penetration into oocytes. Direct chemical exposure on spermatozoa during capacitation was performed, and in in vitro fertilization (IVF) process. Generally, treatment of $500 \mu \mathrm{M}$ or $5 \mathrm{mM}$ chemicals for $30 \mathrm{~min}$ did not change sperm motility and DNA integrity significantly but the fertilization ability in in-vitro fertilization (IVF) process was hampered, indicating that IVF process could detect and distinguish subtle effect of spermatozoa exposed to different chemicals. These findings unveiled the hazardous effects of neonicotinoid insecticides exposure on mammalian sperm fertilization ability as well as embryonic development, raising the concerns that neonicotinoid insecticides may pose reproductive risks on human reproductive health, especially in professional populations. ${ }^{13}$ Acetamiprid is also having most devastating effect causing erectile dysfunction as it acts through multiple inhibitory pathways. ${ }^{14}$ Emamectin benzoate is a biopesticide derivative of the avermectins developed for the control of insect pests. This molecule acts if swallowed and has some contact action. It penetrates leaf tissues (translaminar activity) and forms a reservoir within the leaf. The mechanism of action is unique in the panorama of insecticides. In facts, it inhibits muscle contraction, causing a continuous flow of chlorine ions in the GABA and H-Glutamate receptor sites. Hassina $\mathrm{KO}$ et al, in their study involving male rats, found that treatment with EMB decreased the relative testis weight compared to that treated with $\mathrm{EMB}+\mathrm{Vit} \mathrm{C}$ groups. Histopathological examination showed damage in the tissue architecture of the testes from the EMB-treated group, i.e. oedema in intertubular spaces with vacuolation within tubules, damage involving both germinal and interstitial (Leydig) cells. Histopathological changes were more intense in rats from the EMB-treated group than in those from the EMB+VitC-treated group. ${ }^{6} \mathrm{Vit} \mathrm{C}$ has got anti-oxidant properties and the relative protection of the group treated with EMB along with Vit $\mathrm{C}$ in the mentioned study, as compared with the testicular damage done on the group treated with only EMB, throws light on the possibility of oxidative stress caused by EMB on the male reproductive system although no human study has been carried out so far.

The potential genotoxic effect of thiacloprid formulation on bovine peripheral lymphocytes was evaluated by Galdíková $\mathrm{M}$ et al, using the comet assay and the cytogenetic endpoints: A statistically significant increase in the frequency of DNA damage, as well as in unstable chromosome aberrations ( $\%$ breaks) were found after exposure to the insecticide. ${ }^{15}$ There lies the possibility that such genotoxic effects could also target the spermatozoas in human and cause deleterious effect in the long run.

Thus whatever the underlying mechanism might be, whether it's by causing oxidative stress, hormonal imbalance or by causing DNA damage, the results of the present study; i.e. a decrease in sperm concentration and increase in serum $\mathrm{LH}$ in the subjects exposed to pesticides and also a decrease in sperm density with an increase in serum FSH, LH level in them with prolonged exposure; in light of the abovementioned studies suggest the likelihood that the given pesticides and insecticide used by the study population-cypermethrin, acetamiprid, emmacetin benzoate and thiacloprid has played a major role in causing the sub-fertile or infertile condition of the subjects studied.

\section{CONCLUSION}

Although various causative factors are intermingled in hampering the reproductive function in the selected subjects but long-term exposure to the given pesticides and insecticides could have a definite role in causing harm to the reproductive function of male individuals in this part of the country as evident by the difference in sperm density and serum LH between the two groups of exposed and unexposed subjects. Also, the decrease in sperm density and testosterone and raised serum FSH and LH among the exposed subjects with increased duration of exposure reflects the gonadotoxic effect of pesticides and insecticide in them.

\section{Funding: No funding sources Conflict of interest: None declared \\ Ethical approval: The study was approved by the Institutional Ethics Committee}

\section{REFERENCES}

1. Wangnoo KS. Evaluation of Male Infertility. J Int Med Sc Acad. 2010;23(2):107-9.

2. WHO Pesticide Evaluation Scheme (WHOPES). WHO/Pesticides; 2017. Available at www.who.int.2017.

3. Schafer K. Pesticides and male infertility: harm from the womb through adulthood-- and into the next 
generation. Environmental Health Policy Institute. (PSR); 2010.

4. Meeker DJ. Pyrethroid insecticide metabolites are associated with serum hormone levels in adult men. Reprod Toxicol. 2009;27(2):155-60.

5. Straub L, Villamar-Bouza L, Bruckner S, Chantawannakul P, Gauthier L, Khongphinitbunjong $\mathrm{K}$, et al. Neonicotinoid insecticides can serve as inadvertent insect contraceptives. In Proc. R. Soc. B. 2016;283(1835):20160506. The Royal Society.

6. Khaldoun H. subacute toxicological effects of emamectine benzoate on wistar rat testes. J Internat Scientific Publicat. Agriculture Food. 2015;3:13148591.

7. Toxicological profile for pyrethrins and pyrethroids. Agency for Toxic Substance and Disease Registry. (ATSDR). Atlanta, GA: US. Department of Health and Human Services, Public Health Service; 2003.

8. Jurewicz J. The effect of environmental exposure to pyrethroids and DNA damage in human sperm. Syst Biol Reprod Med. 2015; 61(1):37-43.

9. Evamarie. Disruption of male sex hormones with regard to pesticides: pathophysiological and regulatory aspects. Toxicol Lett. 1999;107: 225-31.

10. Singhet AK. A Current Review of CypermethrinInduced Neurotoxicity and Nigrostriatal Dopaminergic Neurodegeneration. Curr Neuropharmacol. 2012;10(1):64-71.
11. Zalata A, Elhanbly S, Abdalla H, Serria MS, Aziz A, El-Dakrooy SA, El-Bakary AA, et al. In vitro study of cypermethrin on human spermatozoa and the possible protective role of vitamins $\mathrm{C}$ and $\mathrm{E}$. Andrologia. 2014;46(10):1141-7.

12. Fang YL. effects of cypermethrin on male reproductive system in adult rats. Biomed Environ Sci. 2013;26(3):201-8.

13. Gu YH, Li Y, Huang XF, Zheng JF, Yang J, Diao H, et al. Reproductive effects of two neonicotinoid insecticides on mouse sperm function and early embryonic development in vitro. PloS one. 2013;8(7):e70112.

14. Kaur RP, Gupta V, Christopher AF, Bansal P. Potential pathways of pesticide action on erectile function-A contributory factor in male infertility. Asian Pacific J Reproduct. 2015;4(4):322-30.

15. Galdíková M, Šiviková K, Holečková B, Dianovský J, Drážovská M, Schwarzbacherová V. The effect of thiacloprid formulation on DNA/chromosome damage and changes in GST activity in bovine peripheral lymphocytes. J Environment Sci Health, Part B. 2015;50(10):698-707.

Cite this article as: Roy $\mathrm{P}$, Phukan PK, Changmai D, Boruah S. Pesticides, insecticides and male infertility. Int J Reprod Contracept Obstet Gynecol 2017;6:3387-91. 